\title{
ACTIVITIES OF ARBITRAGEURS IN TENDER OFFERS *
}

\author{
FREDERICK B. HENRX $\dagger$
}

Both the Williams Act amendments to the Securities Exchange Act of $1934^{1}$ and the prospectus requirements of the Securities Act of $1933^{2}$ seek to provide the shareholders of the target corporation with sufficient information about the acquiring corporation's takeover bid to enable them to decide rationally whether to tender their shares. But many target shareholders never make this informed choice, largely because no amount of disclosure can inform them of the likelihood that the tender offer will be successful, and thus whether the shares they are willing to tender will be accepted in whole or in part. ${ }^{3}$ Rather than face this choice, many target shareholders sell on the open market. The buyer will probably be an arbitrageur, the professional trader who often decides the outcome of the tender offer by his initial decision to buy target shares and his subsequent disposition of the acquired shares. It has been estimated that arbitrageurs may be responsible for up to 90 percent ${ }^{4}$ of the trading activity in the two securities involved in an uncontested exchange offer and that over 50 percent $^{5}$ of all tenders come through arbitrageurs. This Article examines the mechanics and functions of arbitrage in tender offers and some of the regulatory problems that may arise.

* This Article was prepared in a Workshop in Securities Regulation conducted by Professors Robert $\mathrm{H}$. Mundheim and Morris Mendelsohn of the University of Pennsylvania Law School and Wharton School respectively, and financed by the Brookings Institution. Much of the factual material was developed in conversations with Robert E. Rubin, partner, Goldman, Sachs \& Co.

$\dagger$ B.A. 1967, Dartmouth College; J.D. 1970, University of Pennsylvania. Member, Pennsylvania Bar.

115 U.S.C. $\$ \$ 78 \mathrm{~m}(\mathrm{~d})-(\mathrm{e}), 78 \mathrm{n}(\mathrm{d})-(\mathrm{f})$ (Supp. V, 1970), annending 15 U.S.C. $\S \S 78 \mathrm{~m}, 78 \mathrm{n}(1964)$.

215 U.S.C. $\$ \$ 77 \mathrm{e}(\mathrm{b}), 77 \mathrm{j}$ (a) (1964).

3 Although the Williams Act is intended to uphold the investor's belief in the integrity and openness of the market, see Hearings on S. 510 Before the Subcomm. on Securities of the Senate Comm. on Banking \& Currency, 90th Cong., 1st Sess. 18, 190 (1967) [hereinafter cited as Hearings on $S$. 510], critics have pointed out that the Act fails to provide the most important piece of information that a target shareholder needs: some basis upon which to estimate the likelihood that the takeover will succeed. See Brundey, $A$ Note on Chilling Tender Solicitations, 21 RuTGERS L. REV. 609, 615 n.16, 617-18 (1967).

${ }^{4}$ Huge Profits Out of Tiny Margins, Bus. WEEk, May 28, 1966, at 116 [hereinafter cited as Huge Profits].

5 O'Boyle, Changing Tactics in Tender Offers, 25 Bus. LAw. 863, 866 (1970) [hereinafter cited as O'Boyle]. The percentage includes both cash tender and exchange offers.

It should be noted that few assertions about arbitrage can be made with any certainty. Because of the well-known secretiveness of arbitrageurs, Huge Profits 116 , most descriptions of their activities are based on estimates and speculations. 


\section{Mechanics of Arbitrage}

Arbitrage involves the buying of a security at one price and the simultaneous or nearly simultaneous selling of its equivalent at a higher price usually in the same market. A security has as its equivalent any other security into which it is convertible or exchangeable. ${ }^{6}$ For example, convertible debentures and stock rights issued by a corporation have as their equivalents the corporation's common stock for which they may be exchanged.

In the case of convertible debentures, arbitrage may occur when the debentures are selling at a price lower than the equivalent amount of common stock. The arbitrageur will buy the bonds and sell the stock, making a profit equal to the price differential. For example, if a debenture selling at 1200 is convertible into 40 shares of common stock selling at 30I/2, the arbitrageur can buy a debenture and sell the equivalent amount of common stock ( 40 shares), making a gross profit of 20 dollars per bond. ${ }^{7}$ If he does not own enough shares of the common to cover the sale, he will sell short ${ }^{8}$ and use the common stock received on conversion of the debenture to cover his short position.

The mechanics of arbitrage in an exchange offer are similar. The arbitrageur will buy target shares and sell short an equivalent amount of the offeror's stock. ${ }^{9}$ At the end of the offer, he will exchange the shares of the target which he has accumulated and cover his short position with the shares received in the exchange. His profit will be the price differential between the two securities. Cash tender offers, on the other hand, do not present an opportunity for arbitrage in the classic sense. Because there is no equivalent security to be sold at the time of purchase, no profit can be made from an existing price discrepancy between a security and its equivalent. ${ }^{10}$ The arbitrageur is, however, quite active in cash offers because the acquiring corporation usually offers a cash premium above market for target shares, thus providing an alternative-and profitable-equivalent. He will buy target shares in the open market and tender them for cash on the

6 M. Evans, Arbitrage in Donestic Securities in the United States 21-22 (1965) [hereinafter cited as Evans]; see Twenttetr Century Fund, The Security MARKETS 249-51 (1935).

7 Evans 25.

8 "Selling short" usually denotes a trader's instructions to his broker to sell stock which he does not own but believes will decline. The broker borrows the stock and delivers it to the purchaser. The money value of the borrowed shares is deposited by the broker with the lender. The trader must then "cover" his short position by purchasing the same number of shares he borrowed and giving them to the lender. If the trader initially sold the shares for more than he must pay to "cover," his profit is the difference between the prices.

$\theta$ If the stock offered consists of a new class of securities, the arbitrageur will sell the offered securities on a "when issued" basis.

10 Evans 21-22. 
closing date. If he buys target shares before the price has reacted significantly to the news of the offer, he profits by the price differential between his cost and the offer specified by the acquiring corporation.

The major difference between arbitrage in tender offers and arbitrage in convertible debentures, rights, or warrants is the element of risk. ${ }^{11}$ The latter type of arbitrage is simultaneous and riskless. ${ }^{12}$ In the tender offer context, however, the arbitrageur accumulates a long position in the target's stock, some or all of which may not be accepted by the offeror, and a short position in the offeror's stock which he may have difficulty covering. The arbitrageur must maintain both positions for a relatively long period of time; he cannot cover immediately by exercising the conversion privilege as he can when performing riskless arbitrage in convertible securities because the tender offer must remain open until the specified closing date. ${ }^{\mathbf{1 3}}$ Substantial risks are created for the arbitrageur if the target firm's management engages in defensive measures designed to block the takeover. ${ }^{14}$ Such measures create the risk that the offer will not be consummated, and therefore that the arbitrageur may have difficulty covering his short position profitably. Even if the defensive tactics fail to block the takeover, the delay and uncertainty created may convince the arbitrageur that his capital can be more profitably invested elsewhere. ${ }^{15}$ Of the many defensive measures, perhaps the target's publicity campaign least affects the arbitrageur. This tactic may even play into his hands by creating doubt and confusion in the shareholder's mind. To avoid the difficult task of assessing the competing claims of the target and the offeror, the shareholder may simply sell in the open market. By contrast, tactics creating positive obstacles to the completion of the tender offer seriously threaten the arbitrageur's potential profit. Private or government antitrust suits are most effective because the delay inherent in such litigation allows the target's management to marshal additional defense maneuvers and casts the chilling shadow of unlawful motives upon the acquiring corporation's efforts. ${ }^{16}$ Other factors making arbitrageurs hesitant are the publication of adverse earnings reports or other internal corporate prob-

11 " 'Risk' here does not mean the calculated risk taken in a 'delayed' arbitrage. On the contrary, it means 'risk' in the sense that forces beyond the control of the arbitrager can intervene adversely." Id. 37.

12 Id. 38.

1315 U.S.C. $\$ \S 78 \mathrm{~m}$ (d) -(e) (Supp. V, 1970), amending 15 U.S.C. $\$ 78 \mathrm{~m}$ (1964); see Note, Cash Tender Offers, 83 Harv. L. Rev. 377, 388-89 (1969).

14 See generally Schmults \& Kelly, Cash Take-Over Bids-Defense Tactics, 23 Bus. Law. 115 (1967) ; Note, Defensive Tactics Employed by Incumbent Managements in Contesting Tender Offers, 21 STaN. L. REv. 1104 (1969).

15 This may, in itself, be a victory for the target company, because the loss of arbitrage operations can substantially reduce the chance of a successful takeover.

16 Comment, Eurodollar Financing of Cash Tender Offers: A New Challenge to the Margin Requirements, 118 U. PA. L. REv. 767, 792 n.153 (1970). 
lems. Naturally, all of these risks are inherent to a lesser degree even in friendly mergers and unopposed exchange offers. ${ }^{17}$ Finally, even assuming that the tender offer is successful, if the published bid is for less than the total number of shares outstanding, all of the shares tendered by the arbitrageur may not be taken up. ${ }^{18}$ The arbitrageur is then forced to liquidate his long and short positions in the open market.

Arbitrageurs generally consider exchange offers riskier than cash offers. The registration of newly issued shares in an exchange offer eliminates any element of surprise and lengthens the period of time between the initial announcement of the offer and the specified termination date. The time involved in the registration process increases the vulnerability of the exchange offer. ${ }^{19}$ The SEC examines the transaction in detail; the Antitrust Division of the Justice Department may decide to take action; shareholders may bring suits; and the target's defensive plans may be more fully implemented. By contrast, cash tender offers do not require registration statements and the consequent time for processing. Thus it is less likely that events which could hinder a takeover will occur. For the arbitrageur, then, cash offers present fewer complications than do exchange offers. ${ }^{20}$

In both cash and exchange offers the arbitrageur assumes the risk that the takeover attempt will fail. ${ }^{21}$ The price differential in a cash bid and the spread in market values in a stock for stock offer continue during the early stages of the offer because of this uncertainty. Consequently, the arbitrageur's profits on transactions effected early in the offer may be great. As the termination date approaches and various hurdles (tax rulings, shareholder objections, antitrust difficulties) are cleared, the risk is reduced and the price spread narrows, ${ }^{22}$ reflecting the arbitrageur's increased willingness to establish larger positions. Although his profits per share on transactions undertaken at the narrower spread are smaller, he may trade in large volumes, thus making the overall transaction highly profitable.

Because the arbitrageur's profit is in large measure bound to the success of the acquiring corporation, he may not arbitrage or will do

17 Evans 37; Levy, Arbitrage, Convertible Bonds and the Investor, 194 Con. \& Finan. Chronicle 278 (1961).

18 To the extent that an offer is for "any and all" shares tendered, the arbitrageur's risk is reduced.

19 Cf. Evans 37-38.

20 The arbitrageur's preference for the cash offer seems to be at odds with findings that exchange offers have a greater likelihood of success. A study of all tender offers between 1956 and 1967 showed that the chances of defeating a cash offer were 1 in 3 , while the chances of defeating an exchange offer were 1 in 6 . See Austin \& Fishman, The Tender Take Over, Mergers \& Acouisitions, MayJune 1969, at 13-14.

21 A Feast for the Arbitrageurs, Fortune, Feb. 1969, at 165 [hereinafter cited as Feast for the Arbitrageurs].

22 Id. 
so only to a limited extent if he believes the offer will fail. If, after an arbitrageur has established a position, it appears to him that the offer will be unsuccessful, he will take his profits by liquidating his long and short positions in the open market. ${ }^{23}$ If a sufficient number of arbitrageurs follow this course, the price spread between the stock of the target and the offeror will be maintained. The prices may stabilize at a relatively large spread; if enough arbitrageurs pull out fast enough, the price differential will increase.

The price action of the two stocks is thus a good indicator of what professionals believe to be the chances of the takeover's success. If arbitrageurs believe the offer will be successful, their trading will cause the price of the target company's stock to rise and that of the offeror to fall. As long as they remain in the market, the prices will continue to move slowly together until on the last day of the offer the spread may be negligible. Stable price movements and the gradual narrowing of the spread may thus indicate that arbitrageurs are dominating the market in the two securities.

If arbitrageurs are hesitant, the spread will remain large. One example of a conspicuously wide price spread occurred in the proposed Xerox-CIT merger. ${ }^{24}$ The well-known professional skepticism for this merger was manifested in the large spread, reflecting the arbitrageurs' unwillingness to commit capital to the deal. ${ }^{25}$ The proposed MemorexTechnicolor merger provides a more recent example. Public indications were that the merger would go through as planned. Nevertheless, in spite of assurances from Memorex's president that there were no problems, the spread remained large until the day before the merger was to be consummated. The merger was cancelled just before the deadline, ${ }^{26}$ substantiating the professionals' skepticism. This incident suggests that arbitrageurs may have access to nonpublic information concerning the progress of an offer.

Arbitrage also tends to stabilize the relationship between the prices of both stocks. ${ }^{27}$ By the very nature of his investments the

23 Huge Profits 116.

24 Morgello, The Xerox-CIT Merger Story, Newsweex, Oct. 14, 1968, at 85.

25 Arbitrageurs claim they were never tempted to move into the Xerox-C.I.T. situation, although the spread was often as wide as 36 percent, because, as one of them put it, the statements by the two companies showed they "hadn't done enough work" on the merger to prove they were in earnest.

Feast for the Arbitrageurs 166 . Arbitrageurs were similarly hesitant in the early stages of the proposed merger of White Consolidated Industries and White Motor Corporation. See Abele, Market Place: Traders Careful on White Deal, N.Y. Times, Aug. 20,1970 , at 50 , col. 5 .

26 N.Y. Times, Jan. 17, 1969, at 37, col. 3.

27 In economic terms, arbitrage "tends . . . to balance differences in the supply and demand, as signified by disparity in prices ... The arbitrageur buys the surplus in one market to supply a demand in another. As a result, prices in various markets tend to be equalized." TwENTIETH CENTURY FuND, supra note 6, at 250-51. 
arbitrageur "attempts . . . to isolate himself from the vicissitudes of the market. His strategy is to capture the spread between two . . . securities." 28 Once he has established his position, the arbitrageur is unconcerned with the general condition of the market or any speculative price movements of either security so long as the prices of the two securities continue to move together over the long run.

Once the arbitrageur commits himself to an offer he will generally maintain his positions, gradually increasing his long and short positions over the course of the offer. The arbitrageur will, however, occasionally exert a counterbalancing force on the steadily narrowing price movements by partially reversing his positions. An arbitrageur may do this if the spread narrows below the "required spread"-the narrowest spread within which he believes he can profitably operate. ${ }^{29}$ When the actual spread is greater than this "required spread," he will continue to arbitrage and narrow the spread. If the spread becomes too narrow, the arbitrageur can reverse his positions and take his profits. As the target stock rises in price, many arbitrageurs will be unable to resist this temptation. There will thus be a counter pressure on the prices. Arbitrageurs probably only engage in this practice to a limited extent-to the extent that it is possible to cover their short position in the open market without difficulty. Their primary interest, of course, is to see the offer successfully completed and to tender their accumulated shares of the target so that they can cover their short position in the offeror.

\section{The Function of Arbitrage}

The arbitrageur provides a market for those shareholders of the target corporation who for various reasons desire to sell their shares. ${ }^{30}$ Target shareholders may wish to sell on the open market because of the red tape involved in tendering or because, as noted earlier, they are unwilling to gamble on the outcome of the offer. ${ }^{31}$ Although a target shareholder may receive sufficient information to assess the merits of a proposed takeover, he may still be uncertain whether to tender his shares because he cannot predict what his investment position will be after all the shares are counted. If the offeror requires that a minimum number of shares be tendered before he is required to accept any shares, the target shareholder is uncertain whether his shares will

28 Feast for the Arbitrageurs 165.

29 Evans 40-41.

30 That many shareholders of target corporations sell on the open market is readily apparent: as noted above, text accompanying note 5 supra, $50 \%$ of all tenders may come from arbitrageurs-people acquiring their holdings through purchases on the open market.

31 See note 3 sipra \& accompanying text; Hearings on S. 510, at 38-39, 207. 
be accepted. Even if the takeover is successful, if the offer specifies a maximum number of shares to be accepted, the Williams Act requires that when more than the specified number of shares are tendered in the first ten days, the shares must be accepted on a pro rata basis. ${ }^{32}$ Thus an investor may decide to tender his holdings in the target company but discover later that only a fraction of them have been taken up. ${ }^{33}$ After the mandatory ten day pro rata period, if an offer is on a firstcome-first-served basis, investors will not know when enough shares have been tendered to fulfill the offeror's maximum. To avoid such uncertainties, many shareholders may be tempted to sell in the open market where an ascertainable gain on a definite number of shares is assured. ${ }^{34}$

Prior to 1968, institutional investors avoided the risk that not all tendered shares would be taken up by engaging in the practice of "short tendering." 35 Because most exchange offers provided that certificates representing the tendered shares need not be delivered until after the expiration of the offer, funds and arbitrageurs would tender more shares than they actually owned, thereby insuring that their total block could be accepted by the offeror. But because this practice was thought to give professionals an unwarranted advantage over the amateur, ${ }^{36}$ the SEC promulgated rule $10 \mathrm{~b}-4$ declaring short tendering

3215 U.S.C. $\$ 78 \mathrm{n}(\mathrm{d})(6)$ (Supp. V, 1970), amending 15 U.S.C. $\$ 78 \mathrm{n}$ (1964); see Bromberg, The Securities Laze of Tender Offers, 15 N.Y.L.F. 462, 509 (1969) [hereinafter cited as Bromberg].

33 If for any reason only some of a shareholder's stock is taken up in a cash tender offer, and the offer is followed by a reorganization within the meaning of INT. REV. CODE OF 1954, §368(a) (1), the shareholder may suffer adverse tax consequences. If the merger occurs shortly after the tender offer, the offer and merger may be deemed one transaction for tax purposes. Target shareholders selling only part of their holdings to the offeror will be viewed as having received both offeror stock and cash (boot). Under id., $\$ 356$ (a) (2), such a shareholder may be required to treat the gain realized on the tender offer transaction as ordinary income rather than as a capital gain. See Possible traps for shareholders int tender offers, $28 \mathrm{~J}$. TAX. 256 (1968) ; Interesting use of private ruling in tender offer, $28 \mathrm{~J}$. TAX. 319 (1968). See generally B. BITTKER \& J. Eustrce, Income Taxatron of CorporaTIONS AND SHAREHOLDERS 588-95 (2d ed. 1966). To avoid this possibility, the shareholder may seek to assure capital gains treatment by selling on the market.

34 See Hearings on S. 510, at 209; Bromberg 529; Kelly, Some Observations on Contested Takeover Bids, 15 N.Y.L.F. 619, 626-29 (1969). In exchange offers, additional reasons may arise for selling rather than tendering. Target shareholders are being asked to accept a new investment rather than cash in exchange for their shares. If the offered shares have not been traded on the exchange, they lack the seasoning to give a substantial basis for price comparison, and even if they have been exposed to the market for a long period, the offered shares may simply not comply with the general investment objectives of target shareholders.

35 See Texas Gulf Sulphur-Insider Disclosure Problems 427-28 (1968) [hereinafter cited as Insider Disclosure Problems]; Bromberg 529; O'Boyle 865.

36 See Hearings on $S$. 510, at 188-89, 208-09. Whether the professional had such a great advantage is debatable. The amateur could also short tender if his credit was equal to that of the professional. In addition, the professional who short tendered was legally obligated to deliver the number of shares tendered. If he did not correctly estimate the number of shares to be accepted, he could suffer a substantial loss. See O'Boyle 870 . In practice, however, professionals were able to have more of their shares accepted than amateurs. 
to be a "manipulative or deceptive device." ${ }^{37}$ Consequently, many large stockholders may now sell in the open market rather than risk proration.

Although arbitrageurs also may no longer short tender, they continue to be in a unique position to assume the risk that target holders are often unwilling to take. An arbitrageur accounts for the risk that less than all shares which he tenders will be accepted by adjusting downward the prices he will pay for target shares. For example, assume the target shares are selling at 30 , an offer is made at 40 , and the arbitrageur believes that after the offer the price of the target will drop back to 30 . If the arbitrageur estimates that 80 percent of his stock will be taken up, his calculations would be as follows (for each 100 shares of the target which he tenders): for the 80 percent taken up at 40 , he will receive $\$ 3200$; for the remaining 20 percent, which will be sold on the market at about 30 , he will receive $\$ 600$; he will thus receive a total of $\$ 3800$. To insure the profit necessary to realize the desired rate of return, he may therefore pay only $36^{\mathrm{I}} / 2$, for target shares. If he could be assured that all of his stock will be accepted at 40 , he might pay as much as 38 for target shares. Thus as a result of rule $10 \mathrm{~b}-4$, in cases where pro rata acceptance is a factor, the spread remains wider because the arbitrageur will not pay as much for target shares. The investor is compensating the arbitrageur for assuming the risk of pro rata acceptance which he is unwilling to take.

By buying from target shareholders, the arbitrageur arguably helps to maintain investor confidence in the integrity of the market. The arbitrageur alleviates the confusion arising from the investor's inability to predict an offer's outcome; the selling pressure caused by uncertainty is absorbed by the arbitrageur's buying power. Absent this buying power, an investor might conclude that the securities market does not afford him a reasonable number of equally attractive alternatives by which to effectuate his investment decisions. For the more sophisticated investor, the presence or absence of the arbitrageur, as reflected in the price action of the stocks involved, will indicate the professionals' opinion regarding the outcome of the offer. This investor will therefore be able to make his decision with some assurance of its consequences.

Finally, the arbitrageur also accumulates large blocks of target stock which he will ultimately tender to the offeror. If the offer is successfully completed, his activities will have substantially facilitated the distribution of the offered securities. It should be emphasized, however, that the arbitrageur does not determine the outcome of the

3717 C.F.R. $\$ 240.10 \mathrm{~b}-4$ (1970). 
offer, but rather evaluates its probable success and concludes that he can make a profit. The outcome of the offer is determined by external factors such as shareholder, management, or government reaction and general market conditions. The arbitrageur simply takes a risk in hopes of making a profit, ${ }^{38}$ and is thus no different from any other investor except that he operates on a larger scale and with greater awareness of the risks involved.

\section{Arbitrage AND the 1933 Act}

Arbitrageurs generally commence their buying and short selling operations as soon as a registration statement is filed with the SEC. An arbitrageur's short selling of the offeror's securities at this time does not violate section 5 (a) of the 1933 Act ${ }^{39}$ because the securities traded are not the offered securities, but other securities of the same class; the filing of a registration statement for a public offering of additional securities of an already outstanding class does not require independent dealers to stop their trading activities in the outstanding securities. ${ }^{40}$

But if the arbitrageur covers short sales made prior to the effective date of the registration statement with registered shares received in the exchange, one might argue that he was in fact selling the newly registered securities. Some arbitrageurs attempt to guard against this danger by covering their short positions just after the effective date of the registration statement with "old" securities. After remaining at the risk of the market for about a day, they put out another short. The previously effected short sales are thereby covered with already outstanding securities of the offeror, not with the registered securities received in the exchange. Because the later short sales occur after the registration statement is effective, they may be covered with new securities without violating section 5 (a).

Because the arbitrageur waits until after the registration statement is effective, some doubt arises as to whether the arbitrageur actually does cover his short position with already outstanding securities. It is extremely difficult, if not impossible, for the arbitrageur to cover his short position in the market before the registration statement becomes effective. When he is able to cover his short position after the registration statement becomes effective and some of the newly offered

38 See O'Boyle 865.

3915 U.S.C. $\$ 77 e$ (a) (1964).

401 L. Loss, Securities Regulation 259 (2d ed. 1961). Where the offered security is a convertible security, the arbitrageur may short the common stock underlying the convertible security rather than the security itself. Arbitrageurs will often do this if it is difficult to borrow the convertible security for the short sale. See Feast for the Arbitrageurs 166. 
securities have reached the market, many of the securities used to cover may be the new securities. If in fact some of the securities used to cover can be traced to the registration statement, ${ }^{41}$ the arbitrageur has violated section 5 (a) by effecting a sale of a registered security prior to the effective date of the registration statement.

Even assuming that the arbitrageur covers all short sales with securities that cannot be traced to the registration statement, it nevertheless appears that such a temporary change of position by the arbitrageur violates the spirit of the registration requirements. But under the present system of disclosure in the 1933 Act, it cannot be so considered. The Act requires full informational disclosure through a registration statement for an offering of additional securities of an outstanding class-previously the subject of a registration statementand that the purchaser of a "new" registered security be given the information, while the purchaser of an "old" outstanding security need be given none. Thus if the arbitrageur can complete his sales with presently outstanding securities, he will violate none of the requirements of the 1933 Act. ${ }^{42}$

\section{RULE $10 \mathrm{~b}-6$}

Rule $10 \mathrm{~b}-6$ prohibits an issuer, underwriter, or participating dealer from bidding for or purchasing any security which is the subject of a distribution. Also within the rule's prohibition are bids for, or purchases of, any security of the same class or series, or any right to purchase a security which is the subject of a distribution. ${ }^{43}$ The rule is intended to prevent the practice of artificially raising or supporting the price of a security to increase the return from the offering. ${ }^{44}$

Whether rule $10 \mathrm{~b}-6$ applies to purchases of target securities during exchange offers was, until recently, the subject of some doubt. ${ }^{45}$ The Second Circuit, however, held in Chris-Craft Industries, Inc. v. Bangor Punta Corp. ${ }^{46}$ that Bangor Punta (the offeror) violated rule $10 \mathrm{~b}-6$

41 See Barnes v. Osofsky, 373 F.2d 269 (2d Cir. 1967).

42 Arbitrageurs would seem to be subject to the 40-day posteffective prospectus delivery requirements for sales of the registered securities. The Wheat Report, however, found that this requirement is generally ignored in regular public offerings. SEC Disctosure Study Group, Disclosure to INvestors-A REAPrRaisal of FeDERAL AdMINISTRative Policies UNDER THE '33 and'34 Acts 121-22 (1969). It is doubtful that these requirements are observed any more faithfully in exchange offers.

4317 C.F.R. \$240.10b-6(a) (1970).

44 See Foshay, Market Activities of Participants in Securities Distributions, 45 VA. L. REv. 907 (1959); Whitney, Rule 10b-6: The Special Study's Rediscovered Rule, 62 Mrch. L. REv 567 (1964) ; Comment, The SEC's Rale 10b-6: Preserving a Competitive Market During Distributions, 1967 DUke L.J. 809.

45 InSIDER Disclosure ProbleMs 553-54.

46 [1969-1970 Transfer Binder] CCH FED. SEC. L. REP. đ 92,510 (2d Cir. 1969), aff'd on rehearing, 426 F.2d 569 (2d Cir. 1970) (en banc), aff'g 303 F. Supp. 191 (S.D.N.Y. 1969). 
by purchasing Piper Aircraft (the target) stock in the open market after announcing an exchange offer to Piper shareholders. The court reasoned that because rule $10 \mathrm{~b}-6$ prohibits purchases of "any right to purchase any such security" as well as purchases of the security to be distributed, and because target stock carries the right to purchase the offeror's securities, ${ }^{47}$ purchases of target stock by the specified persons are prohibited.

Bangor Punta argued that purchases of Piper stock decreased the offer's chance of success because they raised the price of Piper stock (thereby decreasing the price differential between the two stocks) and made the offer appear less attractive. ${ }^{48}$ Indeed, the purchase of target stock has been considered a standard defense tactic against an exchange offer. Purchases of target stock, it was thus asserted, ${ }^{49}$ have an effect opposite to that which rule $10 \mathrm{~b}-6$ seeks to prevent and therefore should not be viewed as a violation of that rule. The court replied that this contention

overlooks the decided benefits that purchases of target company stock can produce for the initiator of an exchange offer. ... Small investors especially would be likely to assume that the exchange offer was receiving serious attention and approbation from larger, more knowledgeable investors than they. . . A Absent some indication to the contrary, the target company shareholders would be likely to assume that the entire increase resulted from the offer, not from cash purchases in addition to the offer. ${ }^{50}$

But the court did not explicitly state what the "decided benefits" to the offeror were. The court probably thought the rise in price of target stock would induce the target shareholders to tender their shares. Although a price rise in the target stock is often an indication of the arbitrageur's interest and thus of the likelihood that the exchange offer will be successful, the probability that small investors, for whom the court expressed concern, are aware of this is certainly suspect. It is more likely that only more sophisticated investors would interpret the price rise in this way.

A rise in price of target stock might also induce target shareholders who would not otherwise relinquish their holdings to sell on the open market. Indeed, it was this possibility which in part led to rule

47 But see Lowenfels, Rule 10b-13, Rule $10 b-6$ and Purchases of Target Company Securities During an Exchange Offer, 69 Colun. L. REv. 1392, 1398-99 (1969) (maintaining that this " 'right to purchase' is really in the nature of a mere expectation" when the offer is conditioned on the receipt of a minimum number of shares).

48 See generally Instoer Disclosure Problems 553-54.

49426 F.2d at 577.

50 Id. 
$10 \mathrm{~b}-13^{51}$ Although publicly announced, this rule was not yet effective at the time the purchases in issue in Chris-Craft were made. Rule $10 \mathrm{~b}-13$ prohibits the offeror in either a cash or exchange offer from purchasing target company securities otherwise than pursuant to the tender offer. The release accompanying publication of the new rule states that open market purchases may be manipulative because they "further the tender offer by raising the market price to the point where ordinary investors sell in the market to arbitrageurs, who in turn tender." 52 It is unlikely, however, that the court considered this possibility when it spoke of the "decided benefits" accruing to the offeror from purchases of target stock on the open market, although it did refer to the proposed rule.

Chris-Craft has been criticized for its cavalier treatment of the language and policy of rule $10 \mathrm{~b}-6 .{ }^{53}$ The court itself conceded that it could not find, and the SEC could not present, any precedent for its interpretation of the rule. ${ }^{54}$ Despite these problems, it will be assumed herein that Chris-Craft's interpretation of rule 10b-6, although perhaps incorrect, is nevertheless the law. But it will be argued that rule 10b-6 does not apply to arbitrageurs.

While rule $10 \mathrm{~b}-13$ is by its terms restricted to purchases of a target security by the offeror, ${ }^{55}$ rule $10 \mathrm{~b}-6$ covers a wider class of individuals. The extension of the latter rule by the Second Circuit in Chris-Craft to purchases of target securities during an exchange offer raises the issue whether it applies to arbitrageurs.

To be within the prohibition of the rule, one must be an "underwriter," a "prospective underwriter," or a "broker, dealer, or other person who has agreed to participate or is participating" in a distribution. An "underwriter," for purposes of rule $10 \mathrm{~b}-6$, is one who has "agreed" with an issuer or other person to distribute securities. ${ }^{56}$ The definition of "prospective underwriter" requires the existence of an agreement to submit a bid or an understanding with an issuer that he may become an underwriter. ${ }^{57}$ Thus if the arbitrageur remains totally independent, and makes no commitment or understanding with the offeror, it is difficult to bring him within either of these two classes of persons. $^{58}$ But as the termination of the offer approaches, the

51 SEC Exchange Act Release No. 8712 (Oct. 8, 1969), in [1969-1970 Transfer Binder] CCH FED. SEC. L. Rep. \77,745.

$62 I d$.

53 See Lowenfels, supra note 47, at 1406.

54426 F.2d at $576-77$.

5517 C.F.R. $\$ 240.10 b-13(a)$ (1970).

56 Id. $\$ 240.10 \mathrm{~b}-6$ (c) (1).

57 Id. $\$ 240.10 \mathrm{~b}-6$ (c) (2).

58 Cf. O'Boyle, supra note 5 , at 866 . 
arbitrageur will often cease his arbitrage operations and sign a soliciting dealer's agreement in order to receive the commission on shares tendered to the offeror. He may arbitrage until the last day of the offer, sign the agreement, and tender immediately; or he may stop arbitraging sometime before the offer expires and actually engage in soliciting activities before he tenders. Once he signs the dealer's agreement, he becomes a participating broker-dealer and is clearly within the prohibition of the rule; ${ }^{59}$ additional arbitrage would thus be prohibited.

Whether the arbitrageur could be found to be a "person who has agreed to participate or is participating" in a distribution poses a more difficult question. The very nature and effect of the arbitrageur's activities may make him a participant, whether or not he signs a dealer's agreement. This theory is becoming increasingly important because some arbitrageurs are now reconsidering whether to continue to engage in the practice of signing a dealer's agreement. ${ }^{60}$ The theory rests on a broad reading of the "is participating" language of 10b-6. Because of the arbitrageur's substantial short sales of the offered security, the theory goes, he is assisting the distribution of the offeror's securities and performing a function which, although not similar in practice, is at least equivalent in its effects to that of a soliciting dealer. Such an interpretation, however, is unsupported by the language of the rule. Moreover, identification of the arbitrageur with the interests of the offeror in a takeover attempt rests, as will be shown, on a misconception of his goals and the function he serves in the market.

In its most commonly used sense, a "participant" in a distribution is one who has made an agreement to in some way aid in the distribution. Although a formal agreement need not exist, some nexus with

50 Rule $10 \mathrm{~b}-6$ (a) (3) contains 11 specific exceptions to the coverage of the rule. The exercise of a right to acquire a security is one such exception; this enables the arbitrageur to tender the target shares he holds in his own name.

60 The arbitrageur's reluctance to continue signing the agreement appears to be based on the belief that the SEC disapproves of the practice. Arbitrageurs, however, continue to claim the soliciting fee for their own shares and those of their customers. This fee can be a large element of the arbitrageur's profits and may enable him to exceed the market price of the offer in his purchases of target. If a cash offer is made at $\$ 17.50$, and the soliciting dealer's fee is $\$ .80$ per share, the arbitrageur can pay over $\$ 17.50$ for target shares and his profit will consist solely of the $\$ .80$ commission.

Former Chairman Cohen and General Counsel Loomis thought it was discriminatory that professionals can get the commission for shares they tender from their own accounts, thus in effect commanding a higher price than private investors. Hearings on $S$. 510, at 199 (statement of Chairman Cohen), 209 (statement of General Counsel Loomis).

It has been suggested that the arbitrageur's expectation that he might eventually sign the dealer's agreement makes him a "participant" in the distribution at some earlier date, thus making all target purchases subsequent to that date violative of rule $10 \mathrm{~b}-6$. But for the same reasons that an arbitrageur who never signs an agreement should not be deemed a participant, see text accompanying notes 61-71 infra, if an arbitrageur has no understandings with, and engages in no activities on behalf of offerors, the mere expectancy that the dealer's agreement may be signed should not be enough to make him a participant in the distribution. 
those comprising the distributing group should be required. Suggesting that mere coincidence of interest with the offeror provides this essential nexus distorts the common understanding of "participant."

Neither the SEC nor the courts have been called upon to construe the phrase "a person who . . . is participating." Although the Commission in Shearson, Hammill \& $\mathrm{Co}^{61}$ did find a dealer to be an underwriter within the meaning of rule $10 \mathrm{~b}-6$, the nature of the dealer's activities and the closeness of his relationship with the issuer indicated that he was affirmatively promoting and assisting the issuer's distribution. The Commission reached its conclusion even though the registrant's New York office refused to underwrite the offering, no formal agreement was entered into, and no underwriting fees were paid. The Commission found that one of the issuer's directors was a partner in the registrant; that he worked closely with the issuer during the distribution; that the registrant's facilities were used to carry out the distribution; and that a large number of shares were sold to the registrant's customers and partners. There was, in short, a close working relationship between the issuer and the dealer, and their efforts were coordinated to insure the smooth completion of the distribution.

The kind of relationship which existed between the issuer and dealer in Shearson, Hammill will rarely be found between an offeror and arbitrageur. Arbitrageurs assert that they never arbitrage an offer if they have an investment banking relationship with either party. They take a position in an offer solely for their own profit-the offeror's success is not necessarily essential to the realization of that objective. As long as the spread narrows, arbitrageurs can make substantial profits simply by establishing a position and reversing it. The arbitrageur is, of course, most interested in seeing the offer successfully completed. He has accumulated a substantial short position which he will generally be unable to cover other than through the receipt of the offeror's securities in the exchange. If the takeover begins to look doubtful, the arbitrageur can reverse his position (and if he acted quickly enough he may have saved some of his profits); or, more likely, he can maintain his positions in the hope that the offer will eventually go through. The mere fact that the arbitrageur's interests coincide with those of the offeror and that he may maintain his position even when the prospects are dim reflects the arbitrageur's prediction of the fate of the offer, not a purpose to make it succeed.

Further, arbitrageurs who accumulate a long position in target shares with the expectation of tendering them to the offeror have occasionally found that they can get a better deal from someone else,

61 SEC Exchange Act Release No. 7743 (Nov. 12, 1965), in [1964-1966 Transfer Binder] CCH Fed. SeC. L. ReP. $\llbracket 77,306$. 
as they did in the Crane Company's attempted takeover of Westinghouse Air Brake (WABCO). After being rebuffed by WABCO in an effort to institute friendly merger discussions, Crane determined to make a hostile exchange offer to gain control of WABCO. On April 8. 1968 it announced that it would exchange debentures worth $\$ 50$ for each share of WABCO. Sometime earlier WABCO announced a defensive merger into American Standard. On April 19, originally announced as the last day of Crane's exchange offer, WABCO opened at $\$ 42.25$, and American Standard purchased for cash in the market about $170,000 \mathrm{WABCO}$ shares at an average price of $\$ 49.50$ and immediately sold most of them to friendly mutual funds at an apparent loss of half a million dollars. ${ }^{6}$ Realizing that arbitrageurs would determine the outcome of Crane's offer, American Standard made what it believed was a more attractive offer-approximately $\$ 50$ in cash.

The demand from cash purchasers . . . . proved much more attractive to the arbitraguers, who thus could sell Westinghouse Air Brake and realize cash profits immediately. This also serves another purpose that doesn't escape market observers: It effectively dislodges from arbitrageurs a large amount of Wabco stock that otherwise would have been tendered to Crane but instead now has been bought by American Standard and friendly interests. ${ }^{\text {} 3}$

Crane might have won the battle for control of WABCO had it chosen to sweeten its offer enough to prevent arbitrageurs from selling American Standard. The trading activities that occurred in connection with this control contest indicate that the effect of arbitrage is not always to facilitate the offeror's takeover.

Yet arbitrageurs might still be brought within the expansive reading of the "is participating" language of rule 10b-6. For example, arbitrageurs' assertions of complete independence must be viewed in light of the realities of the Wall Street community. Although arbitrageurs may avoid the obvious kind of relationship found in Shearson, Hammill, more subtle ties in the financial world might pose an equally serious problem. Shearson, Hammill should stand as an obvious warning to arbitrageurs in this respect.

In addition, arbitrageurs may lose some of the independence separating them from the reach of rule $10 \mathrm{~b}-6$ if they claim an exemption from rule $10 a-1 .^{6-1}$ Rule $10 a-1$ proscribes various pricing restrictions

62 Crane Co. v. Westinghouse Air Brake Co., 419 F.2d 787, 791 (2d Cir. 1969).

63 Heard on the Street, Wall St. J., Apr. 23, 1968, at 33, cols. 3-4.

6417 C.F.R. \$240.10a-1 (1970). 
on the making of short sales, but specifically exempts certain arbitrage transactions. ${ }^{0}$ The arbitrage exemption, however, provides that the sale for which the exemption is claimed or its offsetting purchase must be "effected for the bona fide purpose of profiting from a current difference between the price of the security sold and the security owned." An arbitrageur claiming this exemption is compelled to cover his short position with securities received in the exchange. He has thus lost the independence that permits him to sell to a third party as was done in the WABCO fight.

Assuming, however, completely independent arbitrage, contrasting the opinion in Chris-Craft to that of Crane Co. v. Westinghouse Air Brake $C o{ }^{67}$ illustrates still another reason why the extension of rule $10 \mathrm{~b}-6$ to arbitrageurs would be inappropriate: the difficulty of determining what constitutes a manipulative or deceptive practice in the context of a takeover. In Crane, the court intimated that American Standard's market activities were a fraud and deceit on WABCO shareholders:

The net result of this buying was to represent to the public, whose primary source of information is the tape, that there was a great demand for Air Brake at an increased value. It is reasonable to conclude that many Air Brake stockholders who might otherwise have chosen to tender to Crane chose not to do so because their own holdings in Air Brake looked better as the price went up. ${ }^{88}$

The assumption about market behavior upon which liability to WABCO shareholders might be based is directly contrary to that made by the same court in Chris-Craft. The market activities in Chris-Craft were thought to be potentially deceptive to target holders apparently because they would induce them to tender. These two cases thus present the conflicting positions that it is deceptive for an offeror to raise the price of the target security because it increases the chances that his offer will succeed, and that it is deceptive for a competing suitor to raise the price of the target stock because that would deter shareholders from tendering, thereby increasing the chances that the offer will fail.

The basic assumption made in Crane-that as the price of the target rises the offer looks less attractive-is supported by wellestablished "laws" governing the relationship between the price move-

65 Id. \$240.10a-1(d) (7). See generally E. Werss, Registration \& Regulation of Brokers \& DeALeRs 160-61 (1965).

6617 C.F.R. $\$ 240.10 \mathrm{a}-1$ (d) (7) (1970).

67419 F.2d 787 (2d Cir. 1969).

68 Id. at 792-93. 
ments of a security and its equivalent. The price of an "exchangeable" security, such as a convertible debenture, will change if the price of its equivalent (in this case common stock) changes. ${ }^{60}$ Thus as the price of the common goes up, the conversion feature of the convertible security increases in value, and buying pressure will push the security's price upward. For this reason, paragraph (b) of rule $10 \mathrm{~b}-6$ provides that a distribution of a security convertible into another security shall be deemed to include a distribution of the other security. ${ }^{70}$ On the other hand, an increase in the price of an "exchangeable" security will never cause an increase in the price of its equivalent. In the context of an exchange offer, a rise in the price of the target stock will not affect the price of the offeror stock. Thus as the target stock rises, the premium to target shareholders decreases. If rule $10 \mathrm{~b}-6$ is directed against purchases tending to facilitate the distribution of the offered security by artificially raising its price, it is difficult to conceive how purchases of target stock can further this prohibited objective.

But although purchases of target shares may raise the price of the target stock, thereby deterring shareholders from tendering, the price rise may induce some target shareholders to sell in the open market. The arbitrageur will buy and in all likelihood tender, increasing the chances that the offer will be successful. Issuer-induced price rises might stimulate sales to the arbitrageur in situations where the arbitrageur himself may not have been willing to undertake the risks. The manipulative potential of issuer purchases lies in this ability to act as an artificial substitute for, or a boost to, arbitrageur purchases. The issuer in this way may overcome by his own actions the uncertainties and doubts about the merits of the offer which had prevented the arbitrageur from committing his capital to the offer.

Although purchases of target stock by arbitrageurs has the same effect as do purchases by the issuer, they are not artificial or manipulative. Rather, they represent the professional judgment of the free and competitive market as to whether the offer will be successful. Arbitrageurs may stay out of the market, they may be cautiously active, or they may be quite active. Issuer purchases, on the other hand, represent an artificial factor intruding into this competitive bidding process which rule $10 \mathrm{~b}-6$ seeks to preserve. Thus although the application in Chris-Craft of rule 10b-6 to purchases of target stock by

69 See Evans, supra note 6, at 111. See also 3 L. Loss, supra note 40, at 1596 n.121; Comment, supra note 44, at 831 ("[A]ny enhancement of a junior security tends to make the senior security more appealing . . . .").

70 The SEC relied on paragraph (b) of rule $10 \mathrm{~b}-6$ in its brief in the Chris-Craft case in addition to its reliance on the "right to acquire" language. Brief for SEC as Amicus Curiae, Chris-Craft Indus. Inc. v. Bangor Punta Corp., 426 F.2d 569 (2d Cir. 1970). It is clear, however, that the offeror's stock is not convertible into target stock. See Lowenfels, supra note 47 , at 1399. 
the offeror may well be justified, ${ }^{71}$ it would be a mistake to extend it to purchases of target stock by an arbitrageur.

\section{CONCLUSION}

Arbitrage provides an attractive alternative to target shareholders who may not wish to subject their investment to the uncertainties arising in a tender offer situation. The constant pressure on prices resulting from the activities of arbitrageurs also tends to stabilize the relationship of the two securities involved. Finally, the arbitrageur helps to equalize imbalances of supply and demand in two markets and acts as an efficient intermediary in the transference of supply and demand between markets. In performing these functions the arbitrageur incurs a risk, and he expects a profit commensurate with the risk. To the extent that arbitrage of takeovers becomes too costly, the arbitrageur may well devote more of his time to the routine but profitable riskless arbitrage in outstanding securities.

Each new regulation of takeovers raises the arbitrageur's costs. Thus far the arbitrageur has been able to pass these costs on to the public. Rule $10 \mathrm{~b}-4$, for example, increases the risk that the arbitrageur will be prorated. The arbitrageur passes on the cost of this risk by paying less for target shares. Similarly, if the arbitrageur no longer signs a dealer's agreement, he will also make up the lost commission by paying less for target shares. On balance it would seem that these regulations have not imposed a cost disproportionate to the benefit they assure in terms of fair dealing and complete independence of the arbitrageur. But an indiscriminate extension of rule $10 \mathrm{~b}-6$ to arbitrageurs would impose a cost too great to be passed on to the public and one uncompensated for by any real public benefit. Such a regulation would most likely eliminate the arbitrageur as an intermediary in transfers of corporate control, a result hardly warranted merely because arbitrageurs appear to hold the key to the success of many takeovers. Abuses of the sensitive position occupied by the arbitrageur can and should be dealt with through a case-by-case application of rule $10 \mathrm{~b}-6$, similar to that followed in Shearson, Hammill.

71 Chris-Craft and rule 10b-13 are also independently justifiable on the ground "that all stockholders of the target company in an exchange offer must be treated alike; that no large blocks may be purchased for one type or amount of consideration while other stockholders receive another type or amount of consideration." Lowenfels, sipra note 47 , at 1407 . 